\title{
Sequence Identity between the Genomes of Humans and Viruses
}

\author{
Gui-Gao Lin ${ }^{a}$ b Jin-Ming Li ${ }^{b}$ \\ ${ }^{a}$ Graduate School, Peking Union Medical College, and b National Center for Clinical Laboratories, Beijing Hospital, \\ Beijing, PR China
}

\section{Key Words}

Virus-human interactions $\cdot$ Viral diseases $\cdot$ Human genome sequence $\cdot$ Virus genome sequence $\cdot$ Short sequence identity $\cdot$ Basic local alignment search tool

\begin{abstract}
Objective: People exposed to viruses usually do not develop diseases. Viruses cause diseases; however, most of the pathologic effects of these diseases are not caused directly by the viruses but by the side effects of the immune response. It is possible that sequence identity may exist between viruses and humans and may be biologically relevant to the infection of virus. The aim of this study was to find out whether sequence identity exists between viruses and humans. Methods: BLAST searches of virus genome sequences against human genome were performed using the resources of the National Center for Biotechnology Information (NCBI). Results: All the viruses that were compared to humans contain different numbers of short identical regions to the human genome. Each identical region was 20 $30 \mathrm{nt}$ and some were found at multiple sites within the human genome. Conclusion: A new role of the virus in the relationship between viruses and humans was taken into account. We assume that viruses have brought their sequence into the human genome in the long past history of
\end{abstract}

human-virus interaction. In the process, viruses play roles as carriers to transfer external sequence information into the human genome.

Copyright $\odot 2009$ S. Karger AG, Basel

\section{Introduction}

The relationship between viruses and humans is still not completely understood. There are many viruses on earth, but not all of them cause diseases. When exposed to the same virus, some people get sick, but most remain healthy. Viruses cause diseases; however, most of the pathologic effects of these diseases are not caused directly by the viruses but by the side effects of the immune response. Viruses only aim to replicate themselves but not to kill the host. In contrast, human beings try to eradicate all disease-causing viruses. Unfortunately, they have failed. The long-term interaction of humans and viruses may result in a balance. Viruses are possibly not just pathogens. Thus, we speculate that a sequence identity exists between genomes of viruses and humans. The publication of the human genome and large numbers of virus genome sequences enables us to conduct an assessment of identical sequences between humans and viruses [1].

\section{KARGER \\ Fax +41613061234 \\ E-Mail karger@karger.ch}

www.karger.com (c) 2009 S. Karger AG, Basel

0300-5526/09/0524-0196\$26.00/0

Accessible online at:

www.karger.com/int
Jin-Ming Li

National Center for Clinical Laboratories, Beijing Hospital

No. 1 Dahua Road, Dongdan

Beijing 100730 (PR China)

Tel. +86 105811 5053, Fax +86 106521 2064, E-Mail ljm63hn@yahoo.com.cn 
Table 1. Algorithm parameters

\begin{tabular}{ll}
\hline Program & blastn \\
\hline Word size & 11 \\
Expect value & 1 \\
Hitlist size & 100 \\
Match/mismatch scores & $1,-4$ \\
Gap costs & 5,2 \\
Low complexity filter & yes \\
Filter string & L; R -d repeat/repeat_9606; m \\
Genetic code & 1 \\
\hline
\end{tabular}

\section{Methods}

BLAST search of several virus genomes against the genome of humans was performed with the resources of the National Center for Biotechnology Information (NCBI) (http://blast.ncbi.nlm. nih.gov/Blast.cgi?PAGE $=$ Nucleotides $\&$ PROGRAM=blastn\& MEGABLAST $=$ on\&BLAST_PROGRAMS =megaBlast $\&$ PAGE_ TYPE = BlastSearch\&SHOW_DEFAULTS = on \& LINK_ LOC=blasthome). On the web search page above, choose the database 'Human genomic plus transcript' and the program 'Somewhat similar sequences (blastn).' The search parameters are shown in table 1 . The GeneBank accession numbers of virus genomes are accessible on the web (http://www.ncbi.nlm.nih.gov/ sites/entrez? $\mathrm{db}=\mathrm{Genome}$ ). Readers can perform the alignments of all the viruses of interest with the method we introduced.

The following viruses were compared: human immunodeficiency virus 1 (HIV-1, GeneBank accession No. NC_001802), severe acute respiratory syndrome-associated coronavirus (SARSCoV, NC_004718), human papillomavirus 16 (HPV-16, NC_ 001526), hepatitis B virus (HBV, NC_003977), hepatitis C virus (HCV, NC_009825), variola virus (NC_001611), adenovirus-1 (AC_000017), adenovirus 2 (NC_001405), adenovirus 9 (NC_ 010956), adenovirus 11 (AC_000015), adenovirus 17 (NC_ 002067), adenovirus 40 (NC_001454), adenovirus A (NC_ 001460), adenovirus E (NC_003266), B19 virus (NC_000883), Dengue virus type 1 (NC_001477), Dengue virus 2 (NC_001474), Dengue virus 3 (NC_001475), Dengue virus 4 (NC_002640), Japanese encephalitis virus (NC_001437), West Nile virus (NC_ 001563), yellow fever virus (NC_002031), hepatitis A virus (NC_ 001489), hepatitis delta virus (NC_001653), hepatitis E virus (NC_001434), human herpesvirus 1 (NC_001806), human herpesvirus 2 (NC_001798), human herpesvirus 3 (NC_001348), human herpesvirus 4 (NC_007605), human herpesvirus 5 ( $\mathrm{NC}_{-}$ 001347), human herpesvirus 6 (NC_001664), human herpesvirus 7 (NC_001716), human herpesvirus 8 (NC_003409), HIV-2 (NC_ 001722), rabies virus (NC_001542), human parainfluenza virus 1 (NC_003461), human parainfluenza virus 2 (NC_003443), human parainfluenza virus 3 (NC_001796), rubella virus (NC_ 001545), simian virus 40 (NC_001669), influenza A virus, influenza B virus, influenza $\mathrm{C}$ virus, human coronavirus HKU1 (NC_ 006577), human papillomavirus type 6 (NC_001355), human papillomavirus type 18 (NC_001357), enterobacteria phage 13a (NC_011045), and tobacco mosaic virus (NC_001367).

Viruses Bring External Sequence into Humans

\section{Results}

We compared large numbers of DNA virus and RNA virus genomes with the human genome database with the program BLAST [2]. These viruses included the oldest viruses (poxviruses, rabies virus) and newly discovered viruses (SARS-CoV, HIV), small viruses (HBV) and large viruses (variola virus). Unexpectedly, we found that all the viruses that had been compared to humans contain a different number of short regions identical to the human genome (100\% identity). We only list the BLAST results of HIV-1, SARS-CoV, HCV, HPV-16, $\mathrm{HBV}$ and variola virus as representative RNA and DNA viruses due to space constraints (tables 2-7). According to the BLAST results, we found that a DNA virus or a virus with a larger genome often has more identical regions than an RNA virus. For a specific virus, different subtypes contained different numbers of identical regions.

Each of the identical regions was 20-30 nt and some were found at multiple sites within the human genome. Most of these identical regions were located in intergenic regions of the human genome, some were located in regions of human genes, and a few were located in noncoding regions. They were found in either the plus or minus orientation in the human genome. Interestingly, the lengths of these identical regions never exceed $30 \mathrm{nt}$ and they were widespread on the human chromosomes. These short identical sequences were found to be quite unrelated to miRNA sequences [3].

Most of the human genes that contain identical sequences have functions that can be generally termed metabolism according to the Gene Ontology (GO) database [4]. They encode enzymes, binding proteins and transporters involved in DNA replication and cell metabolism.

\section{Discussion}

The publication of the human genome sequence has provided the opportunity to analyze host-virus interactions in a new way. In the current study, we investigate the possibility of sequence identity between the genomes of many viruses and humans. A previous study only compared the genomes of parvoviruses and their respective hosts [3]. They found several 17- to 26 -nt identical sequences, and more importantly, the ontology of host genes in which identical regions were found highlighted several pathways or processes including the cytoskeleton, 
Table 2. BLAST result of $\mathrm{HCV}$

\begin{tabular}{|c|c|c|c|c|c|c|}
\hline $\begin{array}{l}\text { Name of region } \\
\text { of sequence } \\
\text { identity }\end{array}$ & $\begin{array}{l}\mathrm{HCV} \\
\text { sequence } \\
\text { nt }\end{array}$ & Sequence of identity & $\begin{array}{l}\text { Human genes } \\
\text { containing } \\
\text { sequence, } n\end{array}$ & $\begin{array}{l}\text { GeneBank } \\
\text { accession No. of } \\
\text { human genome }\end{array}$ & Features in part of human genome & $\begin{array}{l}\mathrm{E} \\
\text { value }\end{array}$ \\
\hline HCV-human-1 & $9122-9146$ & AАACCAAACTCAAACTCACTCСАТT & 1 & NT_008984.17 & FAT tumor suppressor homolog 3 & 0.038 \\
\hline HCV-human-2 & $2297-2319$ & AGATCCTCCCCTGCTCTTTCACC & 1 & NT_008046.15 & intergenic region & 0.61 \\
\hline HCV-human-3 & $2925-2947$ & AGACCTAGTATTTGACATCACAA & 1 & NT_004559.13 & dynein, axonemal, heavy polypeptide 14 & 0.61 \\
\hline HCV-human-4 & $7238-7260$ & CTGTTCCСTCTCCCAGGAGGAAA & 1 & NT_034772.5 & intergenic region & 0.61 \\
\hline
\end{tabular}

Table 3. BLAST result of HIV-1

\begin{tabular}{|c|c|c|c|c|c|c|}
\hline $\begin{array}{l}\text { Name of region of } \\
\text { sequence identity }\end{array}$ & $\begin{array}{l}\text { HIV } \\
\text { sequence nt }\end{array}$ & Sequence of identity & $\begin{array}{l}\text { Human genes } \\
\text { containing } \\
\text { sequence, } \mathrm{n}\end{array}$ & $\begin{array}{l}\text { GeneBank accession } \\
\text { No. of human genome }\end{array}$ & $\begin{array}{l}\text { Features in part } \\
\text { of human genome }\end{array}$ & $\begin{array}{l}\mathrm{E} \\
\text { value }\end{array}$ \\
\hline HIV-1-human-1 & $3365-3388$ & AAATTATGGTACCAGTTAGAGAAA & 1 & NT_033899.7 & intergenic region & 0.15 \\
\hline HIV-1-human-2 & $7937-7960$ & ACCCCGAGGGGACCCGACAGGCCC & 1 & NW_001838878.1 & intergenic region & 0.15 \\
\hline HIV-1-human-3 & $409-431$ & GAAAGAAAAAATATAAATTAAAA & 1 & NT_010783.14 & intergenic region & 0.6 \\
\hline HIV-1-human-4 & $3116-3138$ & ATTTATCAAGAGCCATTTAAAAA & 1 & NT_010859.14 & THO complex 1 & 0.6 \\
\hline HIV-1-human-5 & $8608-8630$ & ACTTTTTAAAAGAAAAGGGGGGA & 1 & NT_005403.16 & intergenic region & 0.6 \\
\hline HIV-1-human-6 & $3727-3749$ & AAATGAACAAGTAGATAAATTAG & 1 & NT_030059.12 & intergenic region & 0.6 \\
\hline
\end{tabular}

Table 4. BLAST result of SARS-CoV

\begin{tabular}{|c|c|c|c|c|c|c|}
\hline $\begin{array}{l}\text { Name of region of } \\
\text { sequence identity }\end{array}$ & $\begin{array}{l}\text { SARS-CoV } \\
\text { sequence } \\
\text { nt }\end{array}$ & Sequence of identity & $\begin{array}{l}\text { Human genes } \\
\text { containing } \\
\text { sequence, } \mathrm{n}\end{array}$ & $\begin{array}{l}\text { GeneBank } \\
\text { accession No. of } \\
\text { human genome }\end{array}$ & $\begin{array}{l}\text { Features in part } \\
\text { of human genome }\end{array}$ & $\begin{array}{l}\mathrm{E} \\
\text { value }\end{array}$ \\
\hline SARS-CoV-human-1 & $12251-15275$ & TAACATGCTTAGGATAATGGCCTCT & 1 & NT_022792.17 & $\begin{array}{l}\text { polypeptide } \mathrm{N} \text {-acetylgalac- } \\
\text { tosaminyltransferase } 17\end{array}$ & 0.12 \\
\hline SARS-CoV-human-2 & $3184-3207$ & GAGGAAGAAGAAGAGGAAGACTGG & 1 & NT_005403.16 & intergenic region & 0.49 \\
\hline SARS-CoV-human-3 & $15251-15274$ & TAACATGCTTAGGATAATGGCCTC & 1 & NT_008046.15 & intergenic region & 0.49 \\
\hline
\end{tabular}

Table 5. BLAST result of HBV

\begin{tabular}{|c|c|c|c|c|c|c|}
\hline $\begin{array}{l}\text { Name of region of } \\
\text { sequence identity }\end{array}$ & $\begin{array}{l}\text { HBV sequence } \\
\text { nt }\end{array}$ & Sequence of identity & $\begin{array}{l}\text { Human genes } \\
\text { containing } \\
\text { sequence, } \mathrm{n}\end{array}$ & $\begin{array}{l}\text { GeneBank } \\
\text { accession No. of } \\
\text { human genome }\end{array}$ & $\begin{array}{l}\text { Features in part of human } \\
\text { genome }\end{array}$ & $\begin{array}{l}\mathrm{E} \\
\text { value }\end{array}$ \\
\hline HBV-human-1 & $2218-2240$ & CTGCCTTACTTTTGGAAGAGAAA & 1 & NT_025741.14 & intergenic region & 0.21 \\
\hline HBV-human-2 & $1915-1936$ & GTATAAAGAATTTGGAGCTTCT & 1 & NT_011362.9 & $\begin{array}{l}\text { protein tyrosine phosphatase, } \\
\text { receptor type, } \mathrm{T} \text { isoform } 2 \\
\text { protein tyrosine phosphatase, } \\
\text { receptor type, T isoform } 1\end{array}$ & 0.83 \\
\hline HBV-human-3 & $2610-2631$ & AATGAAAAAAGGAGATTAAAAT & 1 & NT_033927.7 & intergenic region & 0.83 \\
\hline
\end{tabular}



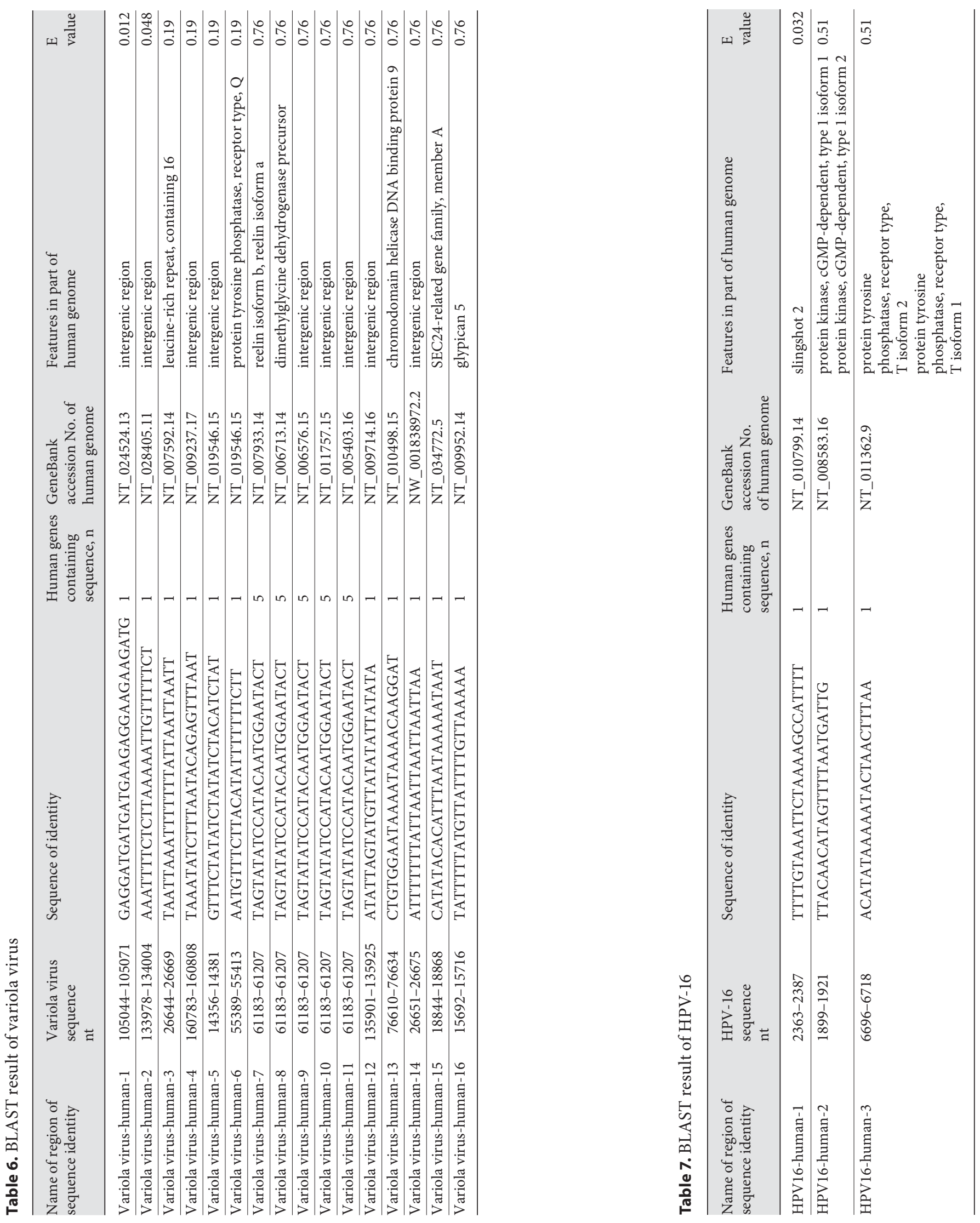
cell adhesion and Wnt signaling. They assumed that the sequence identity is relevant to persistent infection of parvoviruses.

All of the significant hits had an E value $<1$. Specially, the BLAST hit of human herpesvirus 1 had an $E$ value of 6e-04. A search result of chance matches could be excluded.

A certain degree of nucleotide similarity may be due to conserved kinase, polymerase and nucleic acid binding proteins between humans and viruses, which could be classified into orthologs. It is estimated that over $8 \%$ of the human genome is made up of endogenous retroviruses that may contribute to the sequence identity [5].

It is interesting that the phenomenon of sequence identity is universal among all the viruses. HIV might bring their sequences into the human genome by integration [6]; however, this cannot explain the sequence identity of other RNA viruses. For a virus' lack of reverse transcriptase (for example, HCV), it is possible that some parts of transcribed human genomes moved from humans to viral genomes. Herpesvirus gene homologs had been found in the human genome [7]. It is believed that large DNA viruses (herpesviruses and poxviruses) 'acquire' these genes from humans for their own good by mechanisms of immune evasion [8-10]. This may contribute to short regions of sequence identity but still could not explain the phenomenon of other DNA viruses. A model is needed to explain how the viral sequences were transferred to the host genome.

Why the human genome sequence regions are 100\% identical to the viral sequences needs to be investigated further. Presumably, any sequence will deteriorate over time unless some outside force requires it to maintain a conserved base sequence and this outside force would allow a putative function to be established. Viruses may use the identical regions for their own benefits during the long time of evolution.

We have developed the hypothesis that viruses introduced short sequences into the human genome during the long-term history of virus-human interaction. The hypothesis is based on the fact that one identical region of the virus genome was found at multiple sites within the human genome. In the case of the variola virus, 5 different regions of the human genome contain sequences identical to nucleotide 61183-61207 of the virus genome (table 6). In this process, viruses play roles as carriers to transfer exogenous sequence information into humans, not just pathogens.

\section{Acknowledgments}

We thank the Genome Sequencing Consortia for the human genome sequences and all the researchers for the virus genome sequences.

\section{References}

1 Lander ES, Linton LM, Birren B, Nusbaum C, Zody MC, Baldwin J, Devon K, Dewar K, Doyle M, FitzHugh W, Funke R, Gage D, Harris K, Heaford A, Howland J, Kann L, Lehoczky J, LeVine R, McEwan P, McKernan $\mathrm{K}$, et al; International Human Genome Sequencing Consortium: Initial sequencing and analysis of the human genome. Nature 2001;409:860-921.

2 AltschulSF, Madden TL, Schaffer AA, Zhang J, Zhang Z, Miller W, Lipman DJ: Gapped blast and psi-blast: a new generation of protein database search programs. Nucleic Acids Res 1997;25:3389-3402.

-3 Kerr JR, Boschetti N: Short regions of sequence identity between the genomes of human and rodent parvoviruses and their respective hosts occur within host genes for the cytoskeleton, cell adhesion and wnt signalling. J Gen Virol 2006;87:3567-3575.
-4 Ashburner M, Ball CA, Blake JA, Botstein D, Butler H, Cherry JM, Davis AP, Dolinski K, Dwight SS, Eppig JT, Harris MA, Hill DP, Issel-Tarver L, Kasarskis A, Lewis S, Matese JC, Richardson JE, Ringwald M, Rubin GM, Sherlock G: Gene ontology: tool for the unification of biology. The gene ontology consortium. Nat Genet 2000;25:25-29.

5 Griffiths DJ: Endogenous retroviruses in the human genome sequence. Genome Biol 2001; 2:1017.

6 Bushman FD, Craigie R: Activities of human immunodeficiency virus (HIV) integration protein in vitro: specific cleavage and integration of HIV DNA. Proc Natl Acad Sci USA 1991;88:1339-1343.
7 Holzerlandt R, Orengo C, Kellam P, Alba MM: Identification of new herpesvirus gene homologs in the human genome. Genome Res 2002;12:1739-1748.

8 Alcami A, Koszinowski UH: Viral mechanisms of immune evasion. Trends Microbiol 2000;8:410-418.

$\checkmark 9$ Chaston TB, Lidbury BA: Genetic 'budget' of viruses and the cost to the infected host: a theory on the relationship between the genetic capacity of viruses, immune evasion, persistence and disease. Immunol Cell Biol 2001;79:62-66

10 McFadden G, Murphy PM: Host-related immunomodulators encoded by poxviruses and herpesviruses. Curr Opin Microbiol 2000;3:371-378. 